\title{
PERUBAHAN DALAM INOVASI PENDIDIKAN
}

\author{
Yessy Arieana \\ Email: 1810111320004@mhs.ulm.ac.id \\ Program Studi Pendidikan Sejarah Fakultas Keguruan dan Ilmu Pendidikan \\ Universitas Lambung Mangkurat \\ Banjarmasin
}

\begin{abstract}
Abstrak
Inovasi adalah suatu gagasan, ide dan perubahan dalam berbagai bidang. Sedangkan inovasi pendidikan adalah sebuah proses, produk dan ide dala bidang pendidikan. Menurut Prof. Azis Inovasi berarti mengintrodusir suatu gagasan maupun teknologi baru, inovasi merupakan genus dari change yang berarti perubahan. Tujuan dari inovasi pendidikan adalah memaksimalkan (efisiensi, efektivitas dan relevansi) segala kemampuan dalam bidang pendidikan seperti tenaga, uang, sarana prasarana. Jadi inovasi pendidikan adalah suatu idea atau metode yang dirasakan sebagai hal yang baru dan digunakan untuk mencapai tujuan pendidikan atau untuk memecahkan masalah pendidikan. kita sebagai calon seorang pendidik hendaknya bisa menginovasi pendidikan agar tidak membuat para pesera didik cepat merasa bosan. Tujuan untuk menginovasi pendidikan adalah agar siatu pembelajaran itu tidak monoton, sehingga para peserta didik tidak cepat merasa bosan dalam hal belajar dan mengajar.
\end{abstract}

\section{PENDAHULUAN}

Di Indonesia sendiri, pembelajaran menggunakan bantuan teknologi informasi telah diterapkan. Media berbasis teknologi informasi yang mulai dikembangkan adalah aplikasi pembelajaran. Aplikasi pembelajaran adalah sebuah perangkat lunak yang dirancang untuk melaksanakan perintah tertentu tergantung tujuan penggunaannya (Supriyanto, 2015; Dhanta, 2009).

Inovasi ialah untuk memperkenalkan ide-ide baru, dan barang baru, serta pelayanan baru dan cara-cara baru yang lebih bermanfaat. Amabile et al. (1996) mendefinisikan inovasi yang hubungannya dengan kreativitas adalah: 
. Jadi inovasi pendidikan adalah suatu ide-ide, barang, metode, yang dirasakan atau diamati sebagai hal yang baru bagi seseorang atau sekelompok orang baik berupa hasil invensi atau diskaveri, yang digunakan untuk mencapai tujuan pendidikan atau untuk memecahkan masalah pendidikan. Pendidikan adalah suatu sistem, maka inovasi pendidikan mencakup halhal

Inovasi dalam dunia pendidikan dapat berupa apa saja, produk atau sistem, produk misalnya, guru membuat sebuah media pembelajaran mock up untuk pembelajaran. Sistem misalnya, cara penyampaian materi dikelas dengan tanya jawab ataupun yang lainnya yang bersifat metode. Inovasi dapat dikreasikan sesuai pemanfaatannya, menciptakan hal baru, memudahkan dalam dunia pendidikan, serta mengarah pada kemajuan, dengan menggunakan efisiensi, relevansi, dan efektivitas mengenai semua unsur yang terkait dalam pendidikan, seperti inovator dan penyelenggara inovasi (guru dan siswa).

\section{PERAN GURU SEBAGAI SEBUAH PROFESI}

Seorang pendidik yang kreatif biasanya kaya akan ide sehingga tidak ingin anak didiknya merasa bosan dan tertekan pada saat dia memberikan sebuah materi pelajaran kepada anak didiknya. Maka dia akan selalu mencari caraagar anak didiknya merasa nyaman dengan menggunakan cara mengajar yang dia gunakan.

Memperbaharui inovasi dalam dunia kependidikan sering juga diartikan suatu upaya lembaga pendidikan dalam menjembatani masa sekarang dan masa yang akan datang dengan cara memperkenalkan program kurikulum atau metodologi pengajaran yang baru sebagai jawaban atas perkembangan internal dan eksternal dalam dunia pendidikan yang cenderung mengeja efisiensi dan efektivitas (Wijaya dkk, 1991:2). Pada lembaga pendidikan, faktor yang menjadi penentu keberhasilan tujuan pendidikan adalah guru. proses belajar dan pembelajaran loleh seorang guru telah menerapkan prinsip-prinsip dasar peadogik modern dan yang mengutamakan pentingnya perencanaan, pelaksanaan, dan evaluasi. Peran guru dalam inovasi dan pengembangan media pembelajaran sangat diperlukan mengingat guru dapat dikatakan sebagai pemain yang sangat berperan dalam proses belajar mengajar di kelas, hendaknya dapat mengolah kemampuannya untuk membuat media pembelajaran yang efektif dan efisien. Hal ini, menurut Wijaya dkk (1991:2), disebabkan perkembangan jaman yang terus terjadi tanpa henti dengan kurun waktu tertentu. Lembaga pendidikan hendaknya tidak hanya puas dengan metode dan 
teknik lama, yang menekankan pada metode hafalan, sehingga tidak atau kurang ada maknanya jika diterapkan pada masa sekarang. Perkembangan jaman yang begitu pesat dewasa ini membuat siswa semakin akrab dengan berbagai hal yang baru, seiring dengan perkembangan dunia informasi dan Komunikasi. Karena itu, sangat wajar jika kondisi ini harus diperhatikan oleh guru agar terus mengadakan pembaharuan (inovasi).

Salah satu masalah yang dihadapi didalam dunia pendidikan kita sekarang ini adalah sangat rendahnya kualitas pendidikan baik dilihat dari proses pendidikan yang sedang berjalan maupun produk hasil pendidikan itu sendiri. Rendahnya kualitas produk pendidikan tersebut merupakan gambaran kualitas proses penyelenggaraan sistem pendidikan dimana terkait banyak unsur, namun proses belajar mengajar merupakan jantungnya pendidikam yang harus diperhitungkan karena pada kegiatan pembelajaran inilah transformasi berbagai konsep, nilai serta materi pendidikan diintegrasikan.

Dikaitkan dengan tuntutan masa depan yang bukan hanya bersifat kompetitip tapi juga sangat terkait dengan berbagai kemajuan teknologi dan informasi maka kualitas sistem pembelajaran yang dikembangkan harus mampu secara cepat memperbaiki berbagai kelemahan yang ada. Salah satu cara yang dapat dikembangkan adalah mengubah sistem pembelajaran konvensional dengan sistem pembelajaran yang lebih efektif dan efesien dengan dukungan sarana dan prasarana yang memadai. Pembelajaran dengan memanfaatkan sarana teknologi imformasi melalui jaringan internet merupakan salah satu alternatif yang tepat dan dapat mengatasi berbagai persoalan pembelajaran, walaupun sistem pendidikan di Indonesia keberadaannya sangat hetrogen karena terbentur masalah letak geografis yang sangat besar pengaruhnya terhadap kemajuan teknologi informasi.

\section{GURU INDONESIA DAN TANTANGAN PROFESIONALISME}

Berkembangnya revolusi industri 4.0 digunakan rekayasa intelegensia dan internet of thing sebagai pundi-pundi pergerakan dan konektivitas manusia dan mesin. Indonesia pun telah memasuki era revolusi industri 4.0 sejak tahun 2018. Berbagai perubahan yang muncul dan usaha-usaha yang dilakukan oleh pemerintah Indonesia untuk menghadapi dampak dari revolusi industri 4.0 anatara lain meningkatkan mutu dunia pendidikan sehubungan pada era industri 4.0 ini dunia pendidikan harus memuat teknologi pada proses pembelajaranya. pada proses pembelajaran mungkin pihak sekolahan bisa memakai gedged agar lebih praktis dalam penggunaanya. Pendidikan Indonesia dengan pemanfaatan teknologi internet yang super cepat secara tidak langsung telah memicu perubahan proses pembelajaran di Indonesia yang sedang berlangsung di sekolah. Untuk menghadapi perkembangan ini, diperlukan pendidikan yang dapat mencetak generasi yang kreatif, inovatif, serta 
kompetitiPencapaian ini bisa diperoleh secara maksimal dengan cara mengoptimalisasi penggunaan teknologi sebagai alat bantu dalam pendidikan yang diharapkan nantinya bisa menghasilkan output yang dapat mengikuti atau mengubah zaman menjadi lebih baik. Namun kebanyakan sekolah di indinesia masih belum menggunakan kecanggihan teknologi seperti gedged untuk fasilitas pembelajaranya mungkin daerah plosok ataupun daerah yang kurang sinyal internet hal ini menghambat laju pendidikan diindonesia karna di era revolusi industri 4.0 ini memerlukan media komunikasi ataupun kecanggihan teknologi dalam proses pembelajaranyaakan tetapi hal ini masih belum juga berlaku di sekolah yang memiliki sedikit biaya untuk membeli gadged untuk proses pembelajaran, hal ini sangat disayangkan karna peserta didik akan kalah bersaing dengan sesamanya bahkan kalah bersaing dengan Negara tetangga.

Perkembangan didalam dunia ilmu pengetahuan dan teknologi semakin tidak terbayangkan oleh kemampuan akal manusia biasa, oleh karena itu diperlukan suatu pengetahuan, keterampilan dan sikap yang dapat mengikuti perkembangan dan kemajuan ilmu pengetahuan dan teknologi sekarang ini sebagai cara untuk mengimbangi perkembangan dan kemajuan ilmu pengetahuan dan teknologi tersebut. Lembaga pendidikan formal, nonformal dan informal sebagai wahana penghasil sumber daya manusia dengan semua unsur penyelenggaraannya merupakan salah satu kunci dalam menghadapi era teknologi dan informasi. Selanjutnya tenaga pendidik wajib menguasai ilmu pengetahuan dan teknologi dalam mentrasnfer materi pelajaran kepada para peserta didik, sehingga para peserta didik belajar dalam proses pembelajaran akan lebih bermakna atau dengan kata lain

\section{SIMPULAN}

Era abad ke-21 teknologi informasi semakin berkembang dalam kehidupan masyarakat karena dianggap sebagai fasilitas untuk membantu pekerjaan. Banyak terobosan baru teknologi informasi yang tercipta di berbagai bidang. Begitu pula di bidang pendidikan, teknologi informasi seperti PC, laptop, bahkan mobile smartphone digunakan oleh pendidik maupun siswa sebagai alat penunjang pembelajaran. Di Indonesia sendiri, pembelajaran menggunakan bantuan teknologi informasi telah diterapkan. Media berbasis teknologi informasi yang mulai dikembangkan adalah aplikasi pembelajaran. Media pembelajaran adalah salah satu alat bantu mengajar bagi pengajar untuk menyampaikan materi pengajaran, meningkatkan kreatifitas peserta didik dan meningkatkan perhatian siswa dalam proses pembelajaran. Dengan media peserta didik akan lebih termotivasi untuk belajar, mendorong peserta didik menulis, berbicara dan berimajinasi semakin terangsang. Dengan demikian, melalui media pembelajaran dapat membuat proses belajar mengajar lebih efektif dan efesien serta terjalin hubungan baik antara pengajar dengan peserta didik. 
Seorang pendidik yang kreatif biasanya kaya akan ide sehingga tidak ingin anak didiknya merasa bosan dan tertekan pada saat dia memberikan sebuah materi pengajaran kepada anak didiknya. Maka dia akan selalu mencari cara peserta didiknya merasa nyaman dengan mengajar yang dia berikan.

\section{REFERENSI}

Anis, M. Z. A., Putro, H. P. N., Susanto, H., \& Hastuti, K. P. (2020). Historical Thinking Model in Achieving Cognitive Dimension of Indonesian History Learning. PalArch's Journal of Archaeology of Egypt/Egyptology, 17(7), 7894-7906.

Anis, M. Z. A., Susanto, H., \& Mardiani, F. (2021, February). Analysis of the Effectiveness of MPBH: The Mains of Mandai as a Saving Food in Banjarmasin Community. In The 2nd International Conference on Social Sciences Education (ICSSE 2020) (pp. 89-94). Atlantis Press.

Efendi, I., Prawitasari, M., \& Susanto, H. (2021). Implementasi Penilaian Pembelajaran Pada Kurikulum 2013 Mata Pelajaran Sejarah. Prabayaksa: Journal of History Education, 1(1), 21-25.

Susanto, H. (2020). Profesi Keguruan. Banjarmasin: FKIP Universitas Lambung Mangkurat.

Susanto, H., \& Akmal, H. (2018). Efektivitas Penggunaan Aplikasi Pembelajaran Berbasis Mobile Smartphone Sebagai Media Pengenalan Sejarah Lokal Masa Revolusi Fisik Di Kalimantan Selatan Pada Siswa Sekolah Menengah Atas. HISTORIA: Jurnal Program Studi Pendidikan Sejarah, 6(2), 197-206. 
Susanto, H., Irmawati, I., Akmal, H., \& Abbas, E. W. (2021). Media Film Dokumenter Masuknya Islam Ke Nusantara dan Pengaruhnya Terhadap Keterampilan Berpikir Kritis Siswa. HISTORIA: Jurnal Program Studi Pendidikan Sejarah, 9(1).

Sa’ud, U. 2010. Inovasipendidikan. Bandung: Alfabeta.

Rusdiana, A. (2014). Konsep Inovasi Pendidikan. 